\title{
CONSIDERAÇÕES SOBRE O RELACIONAMENTO AMOROSO ENTRE ADOLESCENTES
}

\author{
Sheyla Pinto da Silva*
}

\begin{abstract}
RESUMO: O presente texto é uma tentativa de discorrer sobre a construção social do relacionamento amoroso dos adolescentes, através da perspectiva de que, em cada época histórica, as manifestaçôes sexuais e amorosas, proclamadas como ideais ou não, também são o reflexo das transformaçôes sociais e culturais que os indivíduos vivem. A convivência diária em sala de aula, com crianças e adolescentes, e a observação de algumas de suas atitudes e comportamentos relacionados à vida amorosa e sexual foram subsídios para uma reflexão dessas questóes e para aventar a proposição de algum trabalho educacional nesta área. $\mathrm{O}$ texto levanta algumas questôes como a influência da ação instrumental de sedução e a exigência de qualidade técnica no desempenho sexual e amoroso na formação dos jovens de hoje.
\end{abstract}

Palavras-chave: Relacionamento. Sexualidade. Adolescentes. "Ficar”. Educação.

\section{CONSIDERATIONS AROUND THE LOVE RELATIONSHIPS AMONG ADOLESCENTS}

ABSTRACT: This study is an attempt to discuss the social construction of adolescents' love relationship through under the perspective that, in each historical period, the sexual and love manifestations, claimed or not as an ideal, are also a reflection of the social and cultural everyday life transformations. The fact that I have coexisted with children and adolescents in classrooms and

\footnotetext{
Mestre em Educação pela Faculdade de Educação da UnICAMP; membro efetivo do Grupo de Estudos Interdisciplinar em Sexualidade Humana da mesma instituição; professora da Secretaria Municipal de Educação de Campinas/SP; professora do Curso de Especialização em Educação e Sexualidade Humana da FE/Unicamp. E-mail: wilsons@correionet.com.br
} 
observed some attitudes and behaviors related to their love and sexual life has been the source of food for though, which resulted in a proposal of an educational work in this area. The text arise some questions as the influence of the instrumental action of the seduction and the necessity of technical quality in the sexual and love performance in the training of youth nowadays.

Key words: Relationship. Sexuality. Flirtation. Education.

E ste texto é parte de uma pesquisa de Dissertação de Mestrado que se constituiu um assunto dos mais apaixonantes, pois reuniu os temas "adolescência e relacionamento amoroso", compreendidos como produtos ou criaçôes de uma prática simbólica, de um jogo social e cultural que faz e desfaz maneiras de ser, tecendo de outra forma a realidade, as palavras e os corpos.

A convivência diária, na área educacional, em sala de aula, com crianças e adolescentes e a observação de algumas de suas atitudes e comportamentos relacionados à vida amorosa e sexual trouxeram como conseqüência a anotação de que existe um desconhecimento, entre eles, de questôes envolvidas com sua sexualidade, assim como das mudanças corporais pelas quais passam, ao longo de suas vidas, dos cuidados de higiene e prevenção às doenças, das dificuldades e obstáculos no desenvolvimento da afetividade e auto-estima e, finalmente, do tema que este estudo delimita, que é a sua vivência amorosa.

Foi preciso então um debruçar, com um olhar não inquiridor, mas, sim, questionador, sobre o cotidiano destes adolescentes para, a partir de algumas brechas, tentar melhor entendê-los, refletir sobre algumas das questóes envolvidas e, finalmente, aventar a proposição de algum trabalho educacional nesta área.

Assim, com este intuito, foram sendo feitas anotações do que se ouviu ou viu, durante os momentos em que foram captadas opiniōes, sentimentos e emoções entre os adolescentes, com idades variadas entre 11 e 17 anos, alunos de $7^{\mathrm{a}}$ e $8^{\mathrm{a}}$ séries do ensino fundamental, de uma escola pública municipal da cidade de Campinas (SP). Estes momentos de conversas com os adolescentes foram realizados no espaço da escola em que estudam, situada no mesmo bairro onde moram e onde foram aproveitados alguns dos seus horários livres. As atitudes observadas possibilitaram a apreensão de algumas nuanças dos olhares, das falas, das expressões corporais, dos esbarrões de corpos, dos apertos de mãos e o roçar de pernas, do que poderia 
estar sendo "dito", e do que se apresenta como relevante para a compreensão do momento em que vivem.

Durante o diálogo com os adolescentes, procurou-se interferir o mínimo possível, seja através de perguntas ou observações mais específicas, já que somente a presença do pesquisador pode ter alterado suas "falas" e suas atitudes. As observações, que pareceram ser fáceis à primeira vista, logo fizeram surgir uma pontinha de inquietação: a realidade é mais complexa e difícil de apreender do que se imagina. Ela está no interior de cada sujeito, em suas açôes, no seu pensar e sentir, na sua maneira de se relacionar com o mundo, apresentando assim várias faces, dependendo da construção interior de cada um dos sujeitos e da maneira como eles se conduzem no cotidiano.

Então, como é este relacionamento do sujeito com o mundo, se tal relacionamento acontece a partir da especificidade de cada indivíduo unida à aprendizagem de práticas sociais, constituídas com o outro, em que são inventadas novas formas de relação nas quais estão envolvidas particularidades, prazeres, emoção, sentimentos...?

O debruçar sobre esta reflexão preliminar fez aparecer a abrangência das observações obtidas, pois a penetração no significado das "falas", das vivências e das experiências dos adolescentes, mediadas pela diversidade cultural e pela história de cada um, fizeram com que fosse levantada a necessidade de buscar o passado como referencial histórico para comparação com o presente, não para clarear a continuidade do passado, mas, sim, visando um conhecimento sobre as diferenças e as transformações que possam ter ocorrido e que proporcionaram a constituição do contexto da sociedade de hoje e dos sujeitos que a constituem.

Tornou-se necessário, então, delimitar como seria o caminho para esta busca, que seria a busca de significados e não de provas, que tornam o social um enigma a ser descoberto. Não seria um caminho orientado ou determinado, mas, sim, um caminho cheio de riscos, inclusive aquele de se perder. Este foi o que se mostrou mais tentador a ser seguido, para que através da chama dos significados houvesse a decifração dos seus significantes.

Dessa forma, a escolha deste caminho para a pesquisa tornou possível o ir e vir ao passado histórico, através de uma bibliografia específica, que auxiliou a construção e reconstrução da decifração das representações sociais e individuais do relacionamento amoroso do adolescente de hoje. 


\section{A conquista amorosa}

“(...) a parte amorosa e os sentimentos, que quase ninguém fala, é mais importante" (adolescente feminina de 16 anos). ${ }^{1}$

As transformações que ocorreram durante séculos, nos relacionamentos entre homens e mulheres, adentraram também o século XXI, se constituindo a partir de mudanças sociais e culturais e gerando novos tipos de relações amorosas entre eles.

Estes novos tipos de relacionamentos amorosos, no entanto, não podem ser conceituados dentro de um determinado padrão, sob pena de se cair em um "reducionismo ingênuo", como diz Costa (1998, p. 161), sendo necessário, então, para seu conhecimento, recorrer ao seu sentido popular, isto é, ao que é construído, não pela ciência, mas pela vida cotidiana, pelo imaginário e realidade vivida e produzida por quem dela faz parte. Os relacionamentos se articulam, ainda, ao amor, concentrando as emoções e as esperanças de felicidade. $\mathrm{O}$ amor passa a ser: "(...) uma palavra semanticamente articulada a outras, como prazer, bem-estar, conforto, felicidade, boa vida, alegria ou, ao contrário, a sofrimento, decepção, frustração. Ideais impossíveis, esperanças não correspondidas e assim por diante" (idem, ibid.).

Historicamente, porém, é possível perceber que o amor, mesmo reconhecido de outras formas, de acordo com cada época, muitas vezes, não influenciou a escolha dos parceiros em um relacionamento. Fatores culturais, ideológicos, sociais, políticos e econômicos, principalmente, constituíram requisitos importantes para que algumas escolhas de parceiros acontecessem, não querendo dizer, necessariamente, que os próprios interessados, na maioria das vezes, fossem livres para fazer esta ou aquela opção.

Estes fatores podem ser observados em alguns estudos, literatura e pesquisas que auxiliaram a delinear algumas situações do relacionamento amoroso, principalmente em sociedades ocidentais do século XIX e início do século XX, e que em alguns lugares com valores mais tradicionais podem ser ainda hoje observadas. A busca em correspondências, jornais, fotos e literatura do cotidiano de sociedades ocidentais e tradicionais da época, como as pesquisas do sociólogo Thales de Azevedo, no Brasil, e a História Social da Criança e da Família de Philippe Ariès (1981), tornaram-se fontes de referências preciosas sobre a construção dos relacionamentos amorosos dos indivíduos no decorrer da história. 
A partir da leitura destas pesquisas pode-se traçar o perfil da forma de alguns relacionamentos amorosos que acontecem hoje e que, por sua vez, se acham, ainda, centrados no amor romântico, que, para Costa (op. cit.), é "(...) um valor, ou seja, é algo que aponta para aquilo que devemos ter, ser, ou desejar”, estando o sujeito, portanto, ligado a um ideal de trocas, jogo de sedução e maneira de ser, baseados na perspectiva de que o amor tanto é necessário para conceber o sujeito em uma sociedade para a qual o seu valor decorre de uma inserção socialmente definida, quanto para a constituição individual que se define por regras impostas culturalmente no que diz respeito ao estabelecimento de uma vida a dois.

Encontramos este contexto nos estudos de Thales de Azevedo (1986), o qual traça o histórico de muitas das uniōes no Brasil, no final do século XIX e começo do século XX. ${ }^{2}$ Os arranjos feitos entre as famílias estabeleciam uma relação econômica/social e estas se uniam pelo casamento de seus filhos, em sua maioria muito jovens. As uniōes eram realizadas, principalmente, com o objetivo de perpetuação das obrigações morais e tradiçôes familiares. As relações amorosas praticamente não eram levadas em consideração. O período de namoro e noivado era muito curto e os noivos não tinham, muitas vezes, antes do casamento, nenhum contato físico; podiam se casar sem nem mesmo se conhecerem e o sentimento amoroso de uma das partes, ou ambas, podia ocorrer ou não após o casamento, sendo este considerado indissolúvel.

Esta forma de constituição de novas famílias foi se modificando paulatinamente e, em um primeiro momento, pode-se acreditar que o amor romântico se constituiu um aspecto forte o bastante para sedimentar esta nova transformação da constituição familiar. ${ }^{3}$

Com o consentimento individual no estabelecimento das relações e uniões entre jovens e mesmo adultos, o namoro, o noivado e o casamento passaram a se centralizar principalmente nos valores afetivos de cada indivíduo. A escolha dos parceiros passou a ser pautada pela simpatia, atração física, correspondência afetiva, mas, valores ainda subordinados a grupos e/ou classes sociais, levando em consideração os ambientes que propiciam os encontros entre eles.

Alterações nas formas de escolha nos relacionamentos e uniōes fizeram com que estas deixassem de ser obrigatoriamente centradas em motivos financeiros e de posição social, antes almejados pelos pais que, em sua grande maioria, combinavam e arranjavam os casamen- 
tos de seus filhos. Os jovens passaram a ter maior chance de tornar visíveis as suas emoçóes e possibilidades, cada vez maiores, de resistir a considerações estranhas, como propriedades e estabilidade das instituições como o casamento, tentando dar vazão aos seus próprios desejos e não mais aos de seus pais.

Não obstante tais desejos, outras regras vieram estabelecer novos parâmetros, não mais agora tão centrados nas escolhas dos padrões patriarcais, mas ainda baseados em preceitos de "bom partido", influenciados por requisitos socioeconômicos e pessoais, por grupos de idade, de classe social, de tipo de educação, de religião, tipo racial etc. Assim, mesmo que os namoros, as unióes e os casamentos atendessem a escolhas individuais feitas segundo valores afetivos, que recaíram sobre o grupo a que pertencia o indivíduo, algumas regras tradicionais e preliminares ao namoro persistiram, mesmo não obedecidas totalmente.

Atualmente, as escolhas permanecem individuais e não mais ditadas pelos pais, que no passado obedeciam ao padrão de sociedade em que viviam, mas são diretamente influenciadas pelas regras do mundo de mercado e consumo, apregoadas através da mídia.

Alguns jogos dos namoros mais antigos foram se transformando de acordo com vários fatores, entre eles a modernização das grandes cidades que não permite mais, por exemplo, os olhares lânguidos dos rapazes parados nas esquinas às janelas de suas amadas, a troca de cartas furtivas e muitas vezes nem lidas, porque interceptadas antes, o footing (início do século) ${ }^{4}$ em praças e ruas de passeio, os encontros nos cafés e nas matinées. ${ }^{5}$

A vida moderna, com seus meios de transporte cada vez mais modernos e rápidos, facilitou as idas e vindas de homens e mulheres em suas saídas de casa, tanto à noite quanto durante o dia; a emancipação da mulher e o trabalho feminino que se expandiu fora do lar; o aumento de escolarização e freqüência a cursos, escolas e faculdades; a necessidade de profissionalização para ambos os sexos; as várias opções de lazer, de passeios e viagens; a necessidade de atividades e horas de lazer para afastar os sintomas de estresse; a circulação intensa pelas ruas e shopping para as compras e outros afazeres; a formação de espaços urbanos não destinados só a homens ou mulheres (boates, bares, discotecas e outros), as inovações dos meios anticontraceptivos, as separações de casais e os divórcios, a comunicação fácil e rápida pelo telefone fixo e celular, a Internet (e-mail, 
chat etc.), as várias opções de vestimenta e de moradia, e muito mais... tudo isto somado, alterou significativamente, através dos anos, os padróes das atitudes sexuais e amorosas, assim como também as preliminares ao namoro, o próprio namoro e o casamento, que, assim, se mostram não aprisionados ou parados em um determinado momento histórico.

Uma das práticas de encontros entre jovens que facilitou as escolhas amorosas, característica das décadas de 30, 40 e 50 do século $\mathrm{XX}$, foi o footing. Foi utilizado pelos indivíduos como ocasião para o flirt, ${ }^{6}$ aportuguesado para flerte, as trocas de olhares, sorrisos, gestos significativos de modo dissimulado, que expunham moças e rapazes à conquista e à sedução. No footing, as moças, caminhando lado a lado de suas amigas, de braços dados, avaliavam seus tipos de interesse, tentavam decifrar seus sinais e símbolos exteriores, comparavam os rapazes e estabeleciam, com eles, relaçóes preliminares, exploratórias, de confiança, antes de assumirem qualquer momento de conversa ou intermediação para um futuro namoro, ou mesmo algum compromisso menos sério, isto porque, muitas vezes, estes momentos de flirt podiam significar, também, um pequeno affair sem compromisso, um contato misterioso e breve, porque segundo João do Rio (in: Azevedo, 1986, p. 22) “(...) o gostoso era manobrar com perícia, sem que a dama caia, pois desde que se cai o flirt deixa de o ser. Flirt é apenas pender".

Os rapazes tinham chance de se mostrarem mais abertamente, sem censura ou cobrança antigas, e, porque não dizer, descaradamente como namoradores, olhando, trocando piscadelas, declarando frases galantes e, às vezes, se atrevendo a "pegar e tocar", o que propiciava um misto de "ousadia e recusa". Se o rapaz se tornasse muito insistente, acabava mostrando que não tinha conhecimento das regras de etiqueta, dando margem a que se pensasse que seus objetivos eram apenas imediatos, o que afastava aquelas que não se sentiam ousadas o bastante para "desafiar o perigo".

As moças, ao contrário, não podiam manifestar interesse rapidamente ou demorar muito para demonstrá-lo, pois tinham que ser "sérias e educadas", "comedidas e cautelosas" e "não se oferecerem". No entanto, esta resistência tinha um tempo determinado para acontecer, pois se elas demorassem muito a corresponder, perdiam a chance, às vezes, de estabelecer contato com o rapaz de seu interesse, que podia já estar centrando suas atenções em outra pessoa. Os 
sorrisos e olhares femininos deveriam ser furtivos e nunca de frente para o outro.

A partir da Segunda Guerra Mundial, se intensificou a instauração de uma nova ordem social, que impeliu fortemente as mulheres para o ingresso no mercado de trabalho e com, inclusive, formação técnica específica; para as reivindicaçôes feministas de igualdade perante os direitos do homem (trabalho, igualdade de salário, voto e outros); para o direito à segurança contra a gestação indesejada e limitação do número de filhos, com o uso da pílula anticoncepcional. Em conseqüência da liberação do homem e da mulher para a ampliação de suas manifestações sexuais, uma vivência mais prazerosa foi se tornando cada vez mais imperativa.

Nesta época, vários estudos e pesquisas que já haviam sido realizados, e outros ainda em andamento, vieram revolucionar e levantar polêmicas sobre o que se pensava e se sabia sobre os vários aspectos do comportamento humano ligados ao sexo, ao prazer e ao erotismo, surgindo, assim, um "conceito" sobre a sexualidade humana. O comportamento humano, em tais aspectos, passou a ser relacionado não somente à reprodução e ao ato sexual. Agora, a maioria dos jovens podia escolher, com uma certa liberdade, atração e sentimentos, seus parceiros amorosos e/ou sexuais, dando à sexualidade um caráter mais abrangente, ligando-a a modos de ver e sentir o mundo.

\section{O relacionamento amoroso}

"Sente viajando, é mágico, gostoso, quente" (adolescente masculino de 14 anos).

O debate e a discussão sobre questões de vivência da sexualidade vêm sendo um campo fértil para facilitar as formas e maneiras de relacionamento afetivo, amoroso e sexual entre os indivíduos e as mudanças nas atitudes preliminares ao namoro, noivado e casamento, não só entre os jovens, mas também entre os adultos.

Nesta perspectiva, hoje se pode observar que, desde pequenos, os adolescentes aprendem a se comportar segundo modelos estabelecidos socialmente. Cada vez mais cedo, crianças de até três e quatro anos, seja na escola, na rua e bairro onde moram, acabam "arrumando namoradinhos" entre outras crianças conhecidas, incentivadas, na maioria das vezes, pelos próprios pais, que vêem esta situação como algo natural no mundo de hoje. 
Crianças e adolescentes aprendem, desta forma, que existem sentimentos especiais de afeto, que eles podem sentir por alguém, aprendendo a identificar como diferente e especial a amizade desenvolvida em relação a este menino ou aquela menina, construindo, assim, as relações afetivas entre eles.

Muitos, desde pequenos, têm "namoricos" significativos, coroados por olhares, risadinhas, bilhetinhos, algumas vezes rechaçados pelos que não se interessaram e outras vezes levados adiante, em um processo contínuo de aprendizagem amorosa cada vez maior.

Esta construção percorre a vida do indivíduo e, geralmente, ele só se dá conta disso quando sua atenção se volta mais detidamente para as oportunidades de estar junto com o "outro", para "ficar" com aquele que também está à sua procura. Isto acontece para os adolescentes quando adquirem mais liberdade para saírem de casa sozinhos, irem à escola, ao cinema, freqüentarem "bailinhos", lanchonetes ou passearem no shopping com os amigos e amigas. $\mathrm{O}$ jogo amoroso se inicia, neste momento, timidamente, através de trocas de olhares, roçar de corpos, risadas e sorrisos dirigidos e, na medida em que o adolescente vai adquirindo experiência, adquire também confiança em si mesmo, podendo tornar o jogo menos sutil.

“Tem menina de 9 anos que já está 'ficando', e quando ela fica, ela dá um beijo se vira e sai correndo" (adolescente masculino de 12 anos).

Este "ficar" (estar com alguém) vai, então, se constituindo um jogo erótico realizado a partir das formas básicas e preliminares de relacionamento afetivo e sexual entre os jovens e/ou adolescentes. Pode receber também o nome (entre os adolescentes) de "morder, beliscar", ${ }^{8}$ em uma clara significação de que aos poucos, de bocado em bocado, vão adquirindo experiências, testando sua competência sexual, experimentando diversos sentimentos e expandindo formas de satisfação para seus desejos.

Os adolescentes definem claramente os objetivos de um relacionamento entre eles: momento para que duas pessoas se conheçam, tenham a companhia do sexo oposto e se curtam... sem compromisso.

“(...) o ficar é gostoso porque você fica cada dia com uma menina, não tem compromisso" (adolescente masculino de 15 anos).

As descobertas que o adolescente faz sobre si mesmo ao se relacionar com o outro vêm da aprendizagem sexual e escolhas amoro- 
sas. Eles aprendem a se voltar para o mundo que os rodeia, em um processo de exterioridade, buscando saber quem são e aprendendo a escolher o que querem.

"O ficar é experimentar o que a gente quer e ainda vai querer (...) ficar é descoberta" (adolescente masculino de 15 anos).

Alimentados pela fantasia amorosa, enfatizada pelo mundo que os cerca, os adolescentes podem viver um período de extremo romantismo, em que os sentimentos se exacerbam. Isto pode acarretar o desejo de um amor idealizado e inatingível como, por exemplo, tomarem-se de paixão por ídolos fabricados pela mídia, como artistas e atores de novelas, cantores e líderes de conjuntos musicais, atletas famosos ou outros personagens quaisquer, e até o engajamento em causas ideológicas ou políticas. Para alguns adolescentes, estes momentos podem passar praticamente despercebidos e, para outros, podem se transformar em momentos de intenso conflito, ansiedade e questionamento. Sendo assim, os momentos de experiências, em que se "fica" com uma pessoa, com quem se pode dividir as curiosidades e ansiedades, representam uma oportunidade para saciar muitas das fantasias criadas por paixões não correspondidas.

\section{Uma nova forma de conquista}

“(...) um papo bem legal, chegar perto deixar rolar" (adolescente feminina de 17 anos).

O relacionamento amoroso entre os adolescentes é um dos aspectos de sua sexualidade que ainda permanece bem guardado, e quando citado ou mencionado em estudos e pesquisas, é feito en passant, como assunto passageiro sem maiores conseqüências. Geralmente, também no sistema educacional são mais debatidas as questôes consideradas polêmicas que advêm do exercício da sexualidade centrada no ato sexual, a gravidez não desejada, o aborto, o não uso ou o desconhecimento dos métodos anticoncepcionais, a falta de prevenção e contaminação pelo HIV, as doenças sexualmente transmissíveis, entre outras, questôes estreitamente ligadas às demonstraçôes do funcionamento do corpo biológico e, como tal, ainda desvinculadas da subjetividade de cada indivíduo e de sua construção social, política e cultural.

A sexualidade é assim, ainda, perpassada pela sua naturalização, ou seja, é vista como inerente a cada sujeito, nascendo com ele e não sendo construída pela sociedade em que vive. 
Ante, porém, a uma nova realidade do jogo amoroso, como o "ficar" por exemplo, ocorreram transformações também nas atividades constitutivas do relacionamento amoroso. Algumas mudanças vieram e as regras de etiqueta e de relacionamentos de antigamente se transformaram. Um jovem, para conversar com uma moça, muitas vezes, tinha de pedir permissão para seus pais e levar dois meses para ganhar ou dar um beijo às escondidas. Estas regras foram transgredidas e contestadas pelos movimentos das geraçôes do pósguerra, deixaram de ser assim tão rigorosas e muitos jovens que se conhecem, hoje, mesmo que seja através do antigo footing de seus bisavós e avós, têm a intenção de um breve e passageiro relacionamento. Rapidamente, em uma só e mesma noite, podem partir para trocas de carícias, abraços, beijos e mesmo "transar", " e depois nem mais se encontrarem ou, se isto ocorrer, estabelecer uma amizade e se comportarem como se nada entre eles tivesse acontecido. Alguns podem continuar juntos e quem sabe, depois de uns "rolos", ${ }^{10}$ transformar sua relação em namoro ou casamento.

“(...) quando se conhece uma menina, numa boate, fica só aquela noite como se fosse namorada, depois acabou, vai embora, cada um para sua casa; rola uns beijos, uns abraços, vai para o escurinho, pode rolar uma transa..." (adolescente masculino de 17 anos).

Mesmo sendo o "ficar" um "relacionamento moderno", reconhecido por seu caráter breve, passageiro e descompromissado, definido por ser "um momento de carinho entre duas pessoas" e que, "hoje, todo mundo fica", sob pena de não ser bem visto no grupo de amigos e ser chamado, muitas vezes, de "careta", ainda existem meninas que podem adquirir "fama nada lisonjeira entre os outros jovens" e "os meninos possam se aproveitar..." (adolescente masculino de 16 anos), principalmente, daquelas que não estabelecem seus próprios limites.

Desta forma, são repetidas, ainda, algumas velhas estruturas e cobranças de antigos modelos de comportamentos: quem pode, o que se deve fazer, como e onde "ficar". O "ficar" também possui regras e normas para acontecer e para serem transgredidas.

As preliminares do namoro mais antigo, até os das praças das pequenas cidades do interior de hoje, possuem alguns sinais característicos, que indicam se os interessados perceberam e captaram o interesse do outro e se há interesse do outro em manter contato. Anti- 
gamente, somente os rapazes podiam se mostrar mais abertamente interessados, cabendo às moças um modo discreto de interesse, em uma comunicação mais indireta, através da procura do olhar, do sorriso maroto, do modo de se vestir, da cor da roupa, ou outros detalhes só percebidos, na maioria das vezes, pelo seu eleito. Hoje, no entanto, acompanhando o ritmo rápido das transformações do mundo, o ritual de aproximação, para ambos os sexos, nos encontros nos bares, casas noturnas e praças de shoppings, passou a ser os olhares femininos e masculinos mais diretos e rápidos, através do "secar" 11 o outro ou outra (flerte, mais tarde paquera, e hoje "secar alguém"), que veio substituir os olhares lânguidos das esquinas de antigamente.

“(...) hoje, quase ninguém mais paquera... tem menina que ainda gosta de paquerar, que é coisa de mil novecentos, ela gosta de tudo que é certinho" (adolescente feminina de 15 anos).

As decisões para as aproximaçôes, que antes duravam horas ou dias, e até o início das primeiras carícias ou até mesmo pegar na mão, eram processos gradativos, lentos e tímidos, e se transformaram em açôes relâmpago, em que só o compromisso com a obtenção do prazer momentâneo torna possível a um casal se "conhecer", se acariciar e "transar" em uma só e mesma noite, depois se separar e talvez nunca mais se encontrar ou manter qualquer tipo de relacionamento.

“(...) é um momento único que não pode ser desperdiçado, ficou aquela noite ou aquele dia e no outro acabou" (adolescente masculino de 17 anos).

Entretanto, as demonstrações de cuidados, carinhos e afetos, ligados a sentimentos amorosos, fazem parte do cotidiano da vida dos adolescentes, assim como de todos os indivíduos, e suas variações em torno de um status que lhes são atribuídos, às vezes, podem indicar, segundo Lázaro (1996, p. 24), “(...) variaçõos das concepções do que é o indivíduo e que destino ele pode dar àquilo que nele é movimento em direção ao outro, dissolução, descentramento, perda de si e constituição de uma nova unidade".

Em algumas situações e relacionamentos, por diversos motivos, os sentimentos mais prazerosos podem ficar escondidos, velados, sobressaindo-se a eles outros sentimentos, como a agressividade, a apatia, a raiva, que muitas vezes nem têm suas causas reveladas, mas provavelmente relacionadas à construção social da própria vida 
do sujeito. Todos podem, ainda, sofrer com as exigências, condições e cobranças da sobrevivência diária, agregadas à sobrecarga do trabalho, à necessidade da formação profissional, às escolhas amorosas e às demais situações cotidianas estressantes, produzindo uma demanda forte de vínculos afetivos ligados a uma necessidade de cuidados e carinhos constantes.

Desta forma, ao se examinar o cotidiano do adolescente, o lugar onde ele vive e suas características individuais, adicionados aos aspectos que caracterizam seus relacionamentos, sua comunicação, seu desempenho escolar e sua possível definição profissional, percebe-se que o adolescente vai se estruturando para vivenciar cada situação que se apresentar e que a ele parecerá mais importante o instante de seu acontecimento. Assim, constrói para si mesmo os princípios básicos do diálogo, da tomada de consciência dos sentimentos e emoções e a experiência da autonomia. Podendo mais facilmente construir também seu vínculo afetivo, seu papel sexual e comportamento amoroso, afirmando-se perante o que deseja.

Vigoram, na cultura ocidental, modelos sociais diferentes para a menina e para o menino. Da adolescente mulher, por exemplo, é esperado que ela corresponda a um determinado papel feminino em sua relação amorosa e, para isso, lhe é ensinado que precisa aprender a conquistar o sexo oposto, o masculino, devagar, seduzindo-o, sem declarações muito abertas. Ela deve aprender que dispõe de armas de sedução, podendo usar seu próprio corpo e também outros artifícios que estarão à sua disposição como, por exemplo, vários modelos de lingeries, batons, perfumes, sapatos, roupas etc.

É bom lembrar que muitos desses recursos, até bem pouco tempo atrás, eram mais destinados às mulheres, mas, veladamente, alguns homens também faziam uso deles. As observações feitas no sentido do uso de tais artifícios de sedução, pelas meninas, também cabem, hoje, ao adolescente masculino, assim como, além dos produtos consumíveis, existe, para ambos, o "culto ao corpo", que deve ser bonito e "bem malhado".

Assim, os adolescentes têm, como uma de suas preocupações, em vários momentos da vida, nos diferentes espaços em que se acham inseridos (seja na escola, na rua, nas festas ou em qualquer outro lugar), o desejo de usar como arma de sedução o ideal de beleza centrado em um modelo fabricado pelo consumo. 
Quando um menino ou menina se aproxima deste ideal, todos os outros podem passar a brincar "de fazer a corte" com ele, que ainda é o jogo utilizado para se tentar conquistar alguém para amar, "fazer sexo" ou ambos ao mesmo tempo, mesmo por uma hora ou por alguns minutos apenas.

Ainda que não seja objetivo deste estudo traçar variaçôes entre o amor e o prazer erótico, o gozo e o arrebatamento apaixonado desta situação, mesmo assim, é preciso recorrer a alguns de seus aspectos, pois estarão sempre presentes e, como tal, não podem ser menosprezados. Eles, ainda, podem indicar que o adolescente, de maneira singular e individual e a partir de um jogo de tensão permanente, levanta inúmeras possibilidades de aproximação e de encontros, distinguindo-se do grupo do qual faz parte, tornando-se um indivíduo singular e próprio, que se reconhece e se identifica.

No momento deste arrebatamento, o indivíduo é posto em xeque, revelando toda sua maneira de ser. No livro O erotismo, George Bataille (1980, p. 9) mostra que esta “(...) coesão do espírito humano, cujas possibilidades vão da santidade à volúpia”, faz com que haja a possibilidade do indivíduo desvendar seus segredos a si mesmo, viver sua própria aventura e se isolar do mundo em que vive. Porém, como continuará desejando, também, fazer parte de um todo, a experiência individual terá de ser ultrapassada por ele mesmo.

Para Bataille, ainda, a relação entre continuidade (querer ser parte de um todo) e descontinuidade (experiência individual) é o alicerce da própria condição humana. O adolescente, então, tenta equilibrar esta relação, excedendo, transbordando e superando limites. Sua atividade sexual e amorosa passa a ser submetida ao seu interior, transparecendo eroticamente em múltiplas experiências.

Citando mais uma vez Bataille, três formas de erotismo, cada uma com suas características próprias, manifestam-se de forma diferente: o erotismo sagrado confunde-se com o amor de Deus; o erotismo dos corpos revelar-se-á no desnudamento dos corpos e o erotismo dos corações, quando reconhecido, fundir-se-á com o arrebatamento chamado de amor.

O erotismo, portanto, será o estado de dissolução do ser constituído que, quando ao encontro do outro, se perde e se reencontra, formando uma nova unidade. De outra maneira, diz Bataille, eles são, e isto será o bastante para que, de qualquer maneira, amado e 
amante se encontrem um no outro, e retomem sua auto-suficiência, agora como par amoroso.

Esta concepção de erotismo pode frustrar concepções mais poéticas e líricas do arrebatamento chamado de amor, mas é preciso notar que a voluptuosidade que ela encerra faz com que o adolescente consiga enfrentar, além do seu desejo, que não sabe o que deseja, também a rígida racionalidade que a sociedade desenvolveu, segundo o questionamento de Lázaro (1996, p. 25). Esta perspectiva de amor é uma experiência moderna, e será ele, o amor, uma questão do limite da própria existência do adolescente, a partir da sua experiência amorosa, ou terá ele o significado de enfrentar a racionalidade, como função dos novos modos de organização social desenvolvidos hoje?

\section{Marcas que ficam...}

Finalmente, concluo este texto, parte contida na dissertação de mestrado "A relação amorosa no cotidiano do adolescente: fragmentos e tramas de sedução", através de uma resumida reflexão, a partir de algumas situações que aconteceram em um baile de Dia dos Namorados, realizado na e pela escola onde estudaram os adolescentes da pesquisa citada. Este baile se constituiu um fragmento do cotidiano dos adolescentes que moram no mesmo bairro onde a escola está situada e, portanto, reproduziu em seu interior toda a trama e teia de relações existentes entre eles. Muitas das situaçôes que aconteceram durante o percurso deste baile possibilitaram constatar, de forma evidente, várias questóes abordadas nos dados da pesquisa.

O baile seria um incentivo para contato entre os adolescentes, que poderiam, assim, conversar, "ficar", trocar idéias, se tocar, se conhecer e se reconhecer, expressando, enfim, suas igualdades, diferenças, limitações e inclinações afetivas.

Para participar do baile, foi preciso que os adolescentes fizessem uma inscrição prévia, recebendo, assim, um cartão com uma palavra inscrita. Esta seria a "senha" para que o menino e/ou a menina, ao entrar no espaço da festa, encontrasse um par para dançar pelo menos uma música. Quem recebesse o cartão onde estivesse escrito "lua" procuraria o cartão sol", "calcinha procuraria cueca", "garfo e faca", "cabelo e pente" etc.

Professores e alunos começaram os preparativos uma semana antes. A escola organizou o processo de inscrição, espalhou cartazes e fai- 
xas pelos corredores, decorou o salão do baile com uma grande gravura da Cinderela e do Príncipe Encantado, tentando manter o ideal romântico da data. Também instituiu alguns critérios para a participação dos alunos. Poderiam participar os que estivessem de uniforme e estudassem no período vespertino. A escola, mesmo tentando inovar em sua proposta de integrar os alunos, acabou reproduzindo formas de disciplinar e normatizar relacionamentos e atitudes.

Os adolescentes passaram a semana cochichando nas salas de aulas e formando grupos alegres nos corredores. Acertos e acordos foram feitos através de olhares, conversas e conluios, iniciando um movimento contrário ao que a escola esperava que acontecesse. Descontentes com a forma como o baile seria realizado, os adolescentes mudaram todas as regras do jogo, de acordo com o que vivem, querem e desejam para si.

Este movimento acabou mostrando, também, através do jogo amoroso dos olhares e conversas, que eles já haviam começado a "ficar" com o outro desde o momento do anúncio do baile e que a festa seria o apogeu do encontro de mãos e de sorrisos, de frustrações e desejos, de transgressões e mudanças dos limites e normas estabelecidas.

Os professores deram início ao baile a partir das músicas que os próprios adolescentes escolheram e sobre as quais puderam opinar, o que terminou por mostrar a influência que a mídia exerce sobre eles, ao escolherem músicas com letras que abordam maliciosamente o tema do corpo e que, ao serem dançadas, se expressam através de movimentos corporais de cunho sexual.

Quando os adolescentes adentraram no salão para o baile, apressados, falando e rindo, muitos dos critérios estabelecidos pela escola, já se encontravam desfeitos há muito tempo. A obrigatoriedade do uniforme quase desaparecera para algumas meninas, que portavam tops e mini-saias, haviam se perfumado, pintado os lábios com batom, soltado os cabelos, valorizando algumas partes do corpo e mostrando uma "produção" para a festa. Os meninos capricharam nos topetes, aderindo à moda e impressionando as meninas.

Outras situaçôes também modificaram os planos iniciais da escola, principalmente em relação aos pares para as danças, fazendo com que muitos dos adolescentes soubessem antecipadamente com quem iriam dançar. Alguns dos cartões foram trocados entre eles durante a semana para que os interessados formassem pares com o menino ou menina desejados. Adolescentes que não aceitaram dançar 
com quem tivesse um cartão, cuja palavra combinasse com o do seu, procuraram, antecipadamente, quem estivesse com o cartão da pessoa de sua escolha e, com a anuência de colegas e amigos, fizeram as trocas. Os escolhidos, desta forma, também ficaram sabendo de antemão quem seriam seus pares no baile. Os adolescentes estabeleceram critérios para suas escolhas, experimentando desta maneira seu poder de decidir e optar.

Procedendo desta forma, contrariaram os critérios estabelecidos para o baile, e aceitos por eles previamente, de dançar pelo menos uma música com um parceiro escolhido aleatoriamente. Transgredir foi a tendência deles, à medida que foram se organizando, paralelamente, durante a semana que antecedeu à festa. A idéia do baile foi tomando outro rumo, não esperado pelos professores, constituindo-se, como se pôde verificar depois, em um encontro para dançar e "ficar" com quem se desejasse.

Durante o baile, "rolou" um pouco de tudo. Quem ainda não conhecia seu par ficou sabendo e gostou, dançou e aproveitou a atividade. Quem não gostou, ainda tentou trocar seu cartão com os colegas e, na impossibilidade de troca, o amassou e jogou fora. Meninos e meninas que permaneceram no canto do salão, esperando achar um par ou serem escolhidos, eram os que não correspondiam a padrões estéticos ou modelos sociais de beleza, por serem baixos ou muito altos, mais novos, gordos ou muito magros, sem topete ou porque não possuíam algum adereço, como telefone celular, por exemplo, que os distinguissem dos demais. Por se sentirem rejeitados e fora dos padrões exigidos, alguns alunos foram embora do baile ou se juntaram aos que observavam do lado de fora do salão.

Diante da debandada do baile, as professoras presentes ficaram nervosas, preocupadas com os alunos que não conseguiram par para dançar e uma delas passou a dizer aos alunos que se negavam a dançar: "Quem não dançar, na próxima festa fica de fora...", tentando estabelecer uma obrigatoriedade e uma possível punição, já que eles se negavam a aceitar o critério estabelecido anteriormente.

Enquanto isso, casais rodopiavam pelo salão e, alguns deles, bem juntinhos, não se desfizeram durante todo o baile. No fundo do salão, percebia-se três ou quatro casais, que "resolveram se tocar mais intimamente, trocando 'amassos', abraçando e se beijando", em uma demonstração mais explícita de carícias e carinhos. Um outro 
casal se escondeu atrás das cortinas das janelas laterais. Uma professora, percebendo a movimentação, logo trouxe o casalzinho de volta ao salão.

Uma outra situação aconteceu, ainda mais uma vez, mostrando que os adolescentes não aceitaram mesmo a regra do jogo da escola. Como muitos meninos e meninas ficaram sem par e continuaram procurando uma chance de ficar junto à pessoa desejada ou serem escolhidos, uma professora apareceu com duas vassouras, que começaram a circular pelo salão, de mão em mão. As vassouras, porém, não tiveram nenhum efeito, porque os adolescentes se recusavam a "pagar mico" ou "levar um fora", negando-se, assim, a mudar a situação através da intervenção do adulto.

O baile, que durou duas horas, foi tempo suficiente para que os adolescentes vivessem a atividade de integração, da maneira como se organizaram durante a semana, e não pelos critérios da escola. $\mathrm{O}$ baile mostrou, também, que alguns adolescentes agiram a partir de estereótipos sociais ao segregarem e discriminarem outros adolescentes como parceiros para o relacionamento amoroso, mesmo que tal relacionamento tenha sido breve e passageiro como o "ficar". Isto torna o indivíduo não escolhido incapaz de uma vivência amorosa e/ou afetiva naquele momento. As dificuldades que alguns adolescentes tiveram no baile para estabelecer e vivenciar contatos mais íntimos com o outro mostraram que a construção da sua capacidade de dar e receber afeto é dificultada, quando ele não participa da relação amorosa, tendo ainda que enfrentar o sentimento de se sentir excluído do grupo ao qual deseja pertencer.

Assim, regras e normas que reprimem, regulam, normatizam as atitudes e manifestaçóes amorosas transpareceram claramente, interiorizadas pelos adolescentes, que segregaram e discriminaram outros adolescentes que julgaram não estar dentro dos padrões exigidos. Mas, por outro lado, o movimento de transgressão às normas e regras sociais também subsiste no viver do relacionamento amoroso. Este mesmo movimento pode, ainda, produzir outras regras e normas. Por exemplo, é o que acontece com o "ficar", que se constitui uma relação breve e descompromissada, cuja única obrigação é, justamente, o fato de não ser "longo e nem gerar compromisso".

Uma outra regra criada pelo "ficar", relacionada justamente com um dos fatos observados, foi a segregação e o afastamento do grupo do adolescente que não "ficou", por qualquer motivo que ele 
tenha tido ou que tenha sido criado para ele. A ele foi dificultada também a experiência de viver seu "apaixonamento" e/ou simplesmente "uma maneira legal de conhecer alguém".

Cada nova geração que surge transgride, muda, reforma e modifica as tramas de sedução e conquista amorosa de seus pais e avós, mas, ao mesmo tempo, propõe, constrói e também impõe novas fronteiras para que novas mudanças se estabeleçam.

As situações de segregação e exclusão que se apresentaram no baile levam também a refletir sobre algumas questôes de gênero observadas. A reprodução de algumas atitudes discriminatórias por alguns adolescentes reforçou exatamente o que os modelos sociais esperavam deles: que representassem os modelos elaborados para o sexo masculino e o feminino. Assim, padrões estéticos esperados para cada sexo foram seguidos à risca quando meninos e meninas se "produziram” para o baile. Além disso, durante o baile, as meninas se mostraram mais animadas, falando alto e rindo muito, enquanto os meninos tentaram permanecer fortes, observando primeiro, esperando "licença para se aproximarem".

Alguns adolescentes mostraram-se capazes de experimentar outras possibilidades e outros quereres e, por meio de uma "troca de lugar” com o outro, eles oportunizaram vivenciar outros papéis. Isto aconteceu no baile, por exemplo, quando um menino não precisou convidar uma menina para dançar e pôde se recusar a dançar também. $\mathrm{O}$ mesmo aconteceu com a menina que nem por isso se sentiu rejeitada e pôde decidir mais facilmente com quem queria dançar ou não. Até algum tempo atrás, uma menina jamais poderia esboçar qualquer interesse para dançar com um menino e sequer levantar da cadeira em uma festa para dançar sozinha ou com outra menina. Ambos podem, assim, enfrentar o desafio de descobrir o que querem, tomando as atitudes que acharem melhores.

Os adolescentes, objeto desta pesquisa, também transitam em um sisrtema educacional complexo, formado por valores que tentam contemplar todos os indivíduos, homogeneizando-os em uma pretensa igualdade. No entanto, estes parâmetros estão calcados em aspectos sociais, culturais e políticos que se encontram fora do indivíduo e que reforçam as diferenças econômicas, sociais e culturais, não valorizando o que o indivíduo traz consigo.

As atitudes que precederam ao baile e que também aconteceram durante seu percurso mostraram que os relacionamentos amo- 
rosos, por sua vez, podem ser provocadores de mudanças nas atitudes e nos relacionamentos entre homens e mulheres, mulheres e mulheres, homens e homens e em cada um por si só. Através destas mudanças, eles se posicionam mais sobre suas questôes sexuais ou afetivas, falam sobre elas e têm mais oportunidades de serem ouvidos. Por conta destas mudanças, meninos e meninas, no baile, mostraram mais o corpo, namoraram, conversaram, se beijaram, flertaram, paqueraram, "ficaram"... continuamente estão assim, mudando a si mesmos e modificando, ao mesmo tempo, a estrutura em que vivem, e cada geração, transgredindo os limites, conquistando e estabelecendo novas fronteiras para viver as inúmeras possibilidades de sua imaginação e desejo.

\section{Notas}

1. As "falas" dos adolescentes que aparecem neste texto, assim como as questōes do próprio texto, são reflexōes integrantes da dissertação de mestrado "A relação amorosa no cotidiano do adolescente: fragmentos e tramas de sedução". Vale ressaltar também que os dados e "falas" dos adolescentes deste texto se referem a um grupo de indivíduos que participaram da pesquisa para esta dissertação, não sendo, portanto, e nem podendo ser, referências para qualquer generalização.

2. Azevedo (1986), em seu livro As regras do namoro à antiga, traça o perfil do comportamento de determinados grupos sociais, principalmente a elite brasileira do início do século XX, quanto às regras que deviam ser seguidas para realizar a união de seus filhos segundo interesses econômicos, religiosos, morais e políticos da época.

3. Não foi somente o amor romântico responsável pelas mudanças nas relações amorosas, mas também a Revolução Industrial, a migração de famílias inteiras ou parte delas da zona rural para a vida urbana, o ingresso crescente da mulher no mercado de trabalho e sua maior escolarização, o domínio das formas de anticoncepção, a tecnologia, o alto nível de consumo moderno, a facilidade de trânsito entre cidades, o avanço das formas de comunicação (televisão, Internet, telefone e outras) etc.

4. Footing: Segundo o Dicionário Collins Gem, a palavra vem do idioma inglês e significa "pé, base, fundamento, piso, passo, baile, dança, estado, condição". Fazer o footing era passear, isto é, caminhar pelas avenidas, praças, parques e passeios das cidades que se modernizaram imitando as metrópoles européias, exemplo do Rio de Janeiro, reformado por Moreira Passos no início do século. O costume provavelmente foi importado de Londres ou Paris e introduzido no Brasil na primeira década do século XX pelos franceses, segundo Azevedo (1986). A partir dos anos 30 e até meados dos 60 , constituiu-se em uma oportunidade para encontros entre moças e rapazes em pequenas cidades. Rapazes e moças formavam círculos ao redor de toda a praça, sendo que este era formado pelas moças andando em sentido anti-horário, e os rapazes, circundando o círculo das moças, andavam em sentido horário. Os dois movimentos, em sentidos opostos, facilitavam o "olho no olho" e os sorrisos, pois os jovens ficavam frente a frente em cada volta dada. Quando um rapaz se interessava por uma moça e ela por ele, eles saíam da "roda" para conversar e se conhecerem, saindo dos círculos.

5. Matinèes: Palavra francesa que significa "sessão de cinema, circo ou teatro, (...) que acontece à tarde”, segundo o Pequeno Dicionário Michaelis. 
6. Flirt: Palavra de origem inglesa, que significa "flertar, namorar, paquerar", segundo o Dicionário Collins Gem. É o "olho no olho" com intenções de sedução e conquista.

7. "Ficar": Relacionamento amoroso e/ou sexual moderno, desprovido de maiores compromissos. Pode durar horas ou mesmo alguns minutos, se constituindo como um momento prazeroso, durante o qual duas pessoas se tocam através de carícias e beijos, podendo ou não ocorrer a relação sexual.

8. "Morder, beliscar": Possui conotação de desejo, saborear algo doce, gostoso, apetitoso.

9. Transar: Termo usado para "relacionar-se sexualmente".

10. "Rolo": "ficar" junto alguns dias, semanas, vendo se a relação vai dar certo.

11. "Secar alguém": Tirar "água" do outro para deixá-lo "seco", isto é, pronto, sedento para aceitar a investida amorosa ou sexual.

\section{Referências bibliográficas}

ARIÈS, P. História social da criança e da família. Trad. Dora Flaksman. $2^{\mathrm{a}}$ ed. Rio de Janeiro: Guanabara Koogan, 1981.

AZEVEDO, T. As regras do namoro à antiga: aproximaçōes socioculturais. São Paulo: Ática, 1986. (Coleções ensaios, 118)

BATAILLE, G. O erotismo. Lisboa: Moraes Editores, 1980.

COLLINS GEM: dicionário inglês/português, português/inglês. Glasgow: Harper Collins Publishers, 1998.

COSTA, J.F. Sem fraude nem favor: estudos sobre o amor romântico. $4^{a}$ ed. Rio de Janeiro: Rocco, 1998.

LÁZARO, A. Amor, do mito ao mercado. Petrópolis: Vozes, 1996.

MICHAELIS: pequeno dicionário francês/português, português/francês. São Paulo, Melhoramentos, 1996. 